\title{
The Growing Visibility of Creationism in Northern Ireland: Are New Science Teachers Equipped to Deal with the Issues?
}

\author{
Conor McCrory • Colette Murphy
}

Published online: 24 June 2009

(C) Springer Science + Business Media, LLC 2009

\begin{abstract}
The growing visibility of various forms of creationism in Northern Ireland raises issues for science education. Attempts have been made at political levels to have such "alternatives" to evolution taught in the science classroom, and the issue has received coverage in local press and media. A sample of 112 pre-service science teachers answered a survey on attitudes toward evolution. Preliminary analysis revealed many of these new teachers held views contrary to scientific consensus - over one fifth doubt the evidence for human evolution, and over one quarter dispute the common ancestry of life. Over two thirds indicated a preference for teaching a "range of theories" regarding these issues in science. In addition, 49 pre-service biology teachers viewed a DVD resource promoting "intelligent design" and completed an evaluation of it. The biology teachers also took part in either focus groups or additional questionnaires. A majority took the resource at face value and made positive comments regarding its utility. Many articulated views contrary to the stated positions of science academies, professional associations, and the UK government teaching directives regarding creationism. Most indicated a perception that intelligent design is legitimate science and that there is a scientific "controversy" regarding the legitimacy of evolution. Concern is raised over the ability of these new teachers to distinguish between scientific and non-scientific theories. The suggestion is made that the issue should be addressed directly with pre-service science teachers to make clear the status of such "alternatives." The paper raises
\end{abstract}

C. McCrory $(\bowtie) \cdot$ C. Murphy

School of Education, Queens University Belfast,

Belfast BT7 1HL, UK

e-mail: cmccrory03@qub.ac.uk implications for science education and questions for further research.

Keywords Attitudes to evolution - Creationism Intelligent design $\cdot$ Secondary science education

\section{Introduction}

In the United Kingdom (UK), the legacy of Charles Darwin is currently facing challenges from anti-evolutionists. While considerable media focus has been given in 2008 to the 150th anniversary of the publication of Darwin and Alfred Russel Wallace's original ideas on the theory of evolution by natural selection and in 2009 to Darwin's bicentennial celebrations, anti-evolutionists are engaged in ongoing efforts to undermine evolutionary theory. Northern Ireland (NI) in particular has seen an increase in public efforts to inject non-scientific alternatives, namely creationism and its modern form, intelligent design (ID), into schools and into the science classroom specifically. This paper looks at recent events in the UK, paying particular attention to NI, and presenting data regarding the possible impact of such attempts on pre-service science teachers studying in NI over the past 2 years. In 2006, Truth in Science (TiS), a UKbased group set-up in 2005, sent resource packs promoting ID to the science department of all UK secondary schools. The resource pack includes a DVD resource featuring members of the Discovery Institute ${ }^{1}$, information regarding

\footnotetext{
${ }^{1}$ A Seattle-based group, which has been described as an intelligent design think-tank (Brumfiel 2005; Holden 2006), but more generally describes itself as a public-policy organization, with interests beyond intelligent design in fields such as technology, national defense, transportation, religion and public life, and foreign affairs (Discovery Institute 2007).
} 
online resources and lesson plans critical of evolution, as well as a teaching manual detailing the rationale behind the pack (Truth in Science 2006). One prompt for the current study was to investigate the degree to which prospective biology teachers would be persuaded by the TiS resource, which the authors considered to be superficially convincing. While portraying the position that its main intention is to "promote good science education in the UK," investigations have suggested that the TiS co-coordinating body is made up largely of young-earth creationists (British Centre for Science Education 2007a). The British Centre for Science Education, an independent group that defends science education in the UK, contends that the actual intentions of TiS are explicitly religious, as evidenced by its origins being traced to an appeal in 2004 to the readers of a NI evangelical magazine, Evangelical Times, by Take Heed Ministries (British Centre for Science Education 2007b; Williams 2008a).

\section{UK Attitudes to Evolution and Creationism}

Williams (2008a) has summarized the UK situation with regard to creationism. A 2006 opinion poll of 2,112 adults for BBC Horizon revealed that over two thirds of those surveyed said they believe that creationism (22\%) or ID $(17 \%)$ is the best explanation for the origin and development of life on earth, while almost half (48\%) indicated a preference for evolution (Ipsos MORI 2006). When asked what should be taught in school science classes, the same poll revealed that most (69\%) thought evolution ought to be taught in science, while over $40 \%$ stated that creationism (44\%) and intelligent design (41\%) should be taughtparticipants could select all three options, or none, as they wished. While providing a snapshot of public attitudes to evolution and creationism in the UK, the poll did not distinguish between "teaching" and "teaching about" in its questions and has been criticized for forcing respondents into distinct categories, whereas the reality may be much less straightforward (Spencer and Alexander 2009). A theology think-tank, Theos, report that confusion was a common element of people's choices concerning their views on evolution and creationism:

[O]nly $37 \%$ of people in the UK believe that Darwin's theory of evolution is "beyond reasonable doubt." $32 \%$ say that Young Earth Creationism ("the idea that God created the world sometime in the last 10,000 years") is either definitely or probably true, and 51\% say that Intelligent Design ("the idea that evolution alone is not enough to explain the complex structures of some living things, so the intervention of a designer is needed at key stages") is either definitely or probably true.. (Spencer and Alexander 2009: 9, http://campaigndirector.moodia.com/Client/Theos/ Files/RescuingDarwin.pdf, accessed 22 March 2009)

The Theos survey, rather than forcing respondents to choose one or the other, allowed respondents to state the degree to which they agreed with each position-this accounts for the observation that the figures on relative acceptance of evolution, young-earth creationism (YEC), and ID add up to more than $100 \%$. Spencer and Alexander note that many respondents are confused or to some degree hedging their bets - the overlap in responses is shown when positive responses are reduced to "definitely true," which results in $11 \%$ and $14 \%$ firm agreement for YEC and ID, respectively. From this it, would appear that many who are firm adherents of either YEC or ID (as described above) are less firm in their agreement with the other proposition but may agree to some extent. This could even extend into partial agreement with evolution as described above and partial agreement with both YEC and ID. The equivocal nature of public attitudes to evolution in the UK is apparent when these studies are contrasted with a comparative study of the USA, Japan, and 32 European countries where $75 \%$ of UK respondents agreed with the statement "Human beings, as we know them today, developed from earlier species of animals," with $17 \%$ disagreeing and $8 \%$ unsure (Miller et al. 2006). This item makes no mention of God, whereas the Ipsos MORI item pertaining to evolution included the caveat "God played no part in the process," making it necessarily atheistic. In summary, there is a significant minority of the UK public that does not accept evolution, and this varies depending on whether the questions asked pertain to human or general biological evolution (with acceptance of evolution lower when "humans" are referred to) and whether they contain a theological element (with acceptance of evolution lower when it is not presented as necessarily atheistic).

\section{Creationism in Northern Ireland}

Opposition to evolution in NI is visible in the political and religious domains and typically involves an overlap of activity in both areas, often receiving media attention. Currently, the largest political party in NI is the Democratic Unionist Party (DUP), and until recently, the Reverend Ian Paisley was the party leader. Historically, the DUP was noted for its strong links with the Free Presbyterian Church, a Protestant church in the fundamentalist and evangelical tradition founded by Paisley in the 1950s, and with its strongest support base in NI. Rev. Paisley resigned his position as First Minister of the NI Assembly (legislature of NI, based at Stormont, in Belfast) in May 2008, 
having already vacated his role as moderator of the Free Presbyterian Church following concerns over his dual role in both organizations (BBC News 2008).

DUP members have been involved in most of the publicly visible attempts to undermine evolution education in NI. The recent attempts to include alternatives to evolution in the science classroom can be traced to early 2006, when a DUP delegation met with a group of parents "to discuss how subjects like biology, physics, and geography are taught in schools across Northern Ireland. These concerns relate to the way in which the age of the earth and the origins of life including mankind came about and the theory of evolution verses [sic] intelligent design." (Dawson 2006, http://www.georgedawson.org/design.htm, accessed 1 March 2007). One of the delegates, Mervyn Storey, at the time of writing occupies the position as chair of the Education Committee at the NI Assembly (Northern Ireland Assembly 2008a). A position statement on intelligent design that came from the 2006 meeting stated:

It is clear that in our schools the faith of many thousands of pupils is being actively denigrated on a daily basis and that the schools system is being used by education authorities to indoctrinate people against their own religious convictions. This must stop. (Dawson 2006, http://www.georgedawson.org/design. htm, accessed 1 March 2007). ${ }^{2}$

There is no evidence as to who initiated the meeting or as to whether this position is embraced by the DUP as a whole, although the online statement had a DUP party logo beside it. In September 2007, Lisburn, a small city south of Belfast, briefly became the center of a media storm following its council passing a motion, proposed by the DUP's Paul Givan, to contact all Lisburn secondary school science departments asking them to supply information as to the plans they had to "develop teaching material in relation to creation, intelligent design and other theories of origin" (Lisburn City Council 2007, private communication). Local press followed the controversy (Ulster Star 2007; Henry 2007), and NI's largest circulating newspaper soon contained an editorial concerning the move:

The eyes of the world will surely be focused on Lisburn, now that the city council has voted to write to post-primary schools encouraging them to teach "intelligent design" and "creationism" as alternatives to the theory of evolution, explaining the origins of life. If the schools were to obey, they would be reopening an old debate, pitting religious fundamentalists against the scientific establishment. (Belfast

\footnotetext{
The position statement remained online from spring 2006 until a few months after the death of DUP member George Dawson in 2007.
}

Telegraph 2007, http://www.belfasttelegraph.co.uk/ opinion/viewpoint-the-world-according-to-lisburn-folk13479536.html, accessed 25 October 2008)

The Lisburn move and other creationist activity resulted in critical responses from academics in both the School of Education and the School of Biology at Queens University (BBC Northern Ireland 2007; Montgomery 2007). At the same time the Lisburn controversy was brewing, several questions concerning the teaching of "theories other than evolution" were put to Catriona Ruane, the Education Minister at the NI Assembly by David Simpson of the DUP (Northern Ireland Assembly 2007a). The questions asked what sort of support or teaching materials would be available to teachers wishing to include alternatives to evolution in their lesson. Ruane's responses remained noncommittal, explaining that schools could choose their own resources to support lessons and refrained from any criticism of the supposed alternative theories. Two months later, Mervyn Storey joined Simpson in raising seven items for discussion at the NI Assembly (Northern Ireland Assembly 2007b), directed to the education minister. This time, the items asked whether teachers could use their own judgment to decide whether non-evolutionary explanations of the origin and development of life had a sufficient evidence base to warrant their inclusion in the science classroom. Ruane's responses were more substantial, alluding to the position statement on creationism/ID of the Association for Science Education (the UK's professional association for science teachers and educators) while acknowledging that the NI "revised curriculum" allowed for consideration of alternatives to evolution and distinguishing between evidence-based scientific theories and alternatives that would be more suited to religious education. When Storey revisited the matter in the NI Assembly in January 2008, Ruane refused to engage beyond referring to previous answers (Northern Ireland Assembly 2008b). Storey has made it clear that his preference is not just for the inclusion of young-earth creationism in the science classroom (BBC Sunday Sequence 2008) but also for the actual removal of evolution:

Creationism is not for the RE class because I believe that it can stand scientific scrutiny and that is a debate which I am quite happy to encourage and be part of... You can't have one very narrow theory... This is not about removing anything from the classroomalthough that would probably be the ideal for mebut this is about us having equality of access to other views as to how the world came into existence and that I think is a very, very important issue for many parents in Northern Ireland. (News Letter 2008, http:// www.newsletter.co.uk/news/your-views-Call-to-teach. 4360514.jp, accessed 10 November 2008; Dumigan 
2008, http://www.irishtimes.com/newspaper/ireland/ 2008/0807/1218047756470.html, accessed 8 August 2008)

The recent comments from Storey, while in part adopting the language of "equality" associated with US antievolutionists, mark a departure from most advocating the language of "equal-time," with Storey indicating that his preference would be for evolution to be removed from the science classroom. Storey's calls for creationism in science education have not been confined to the arena of school science. In 2007, Storey also called for the inclusion of creationist explanations in the tourist exhibits at the Giant's Causeway (BBC Radio Ulster 2007), a 50-60 million yearold basalt formation on NI's north coast, which is a UNESCO World Heritage Site. That Storey currently occupies the chairperson position for the education committee at the NI Assembly is a cause for concern for science education.

\section{Attitudes to Evolution in Northern Ireland}

While a few recent opinion-poll surveys on attitudes toward evolution and creationism have been conducted in the general UK population, data specific to NI is sparse. The only existing evidence is three social surveys in 1998, 2000, and 2009 and two studies of secondary school pupils. The 1998 Northern Ireland Life \& Times survey (NILT), an annual social attitudes study, included a module on public understanding of science (ARK 1999), of which only one item pertained to evolution. Respondents were asked to comment on their perception of the following statement, "Human beings as we know them today developed from earlier species of animals." Overall, two thirds $(66 \%)$ responded that they thought the statement was definitely or probably true, over one quarter $(28 \%)$ indicated that they thought it was definitely or probably untrue, while the remainder did not know. In 2000, the NILT included the "Environment" module from the International Social Survey Programme (ISSP), which asked respondents how true they thought the statement "Human beings developed from earlier species of animals" was (ARK 2001). Just over half $(53 \%)$ of respondents thought the statement was definitely or probably true, while $31 \%$ thought it was definitely or probably untrue, and the remainder did not know. The items refer only to human evolution, and it has been demonstrated that the response to questions on attitudes toward evolution vary dependent on the inclusion of "human" in the wording (Coalition of Scientific Societies 2008) - acceptance of evolution being slightly higher when "human" is omitted from the question wording. It is not possible to say whether the attitudes toward human evolution and its relative acceptance or rejection extends to the evolution of non-human life. The survey also indicated a higher level of acceptance of human evolution in the 1998 and 2000 surveys as definitely or probably true among Catholics (76\% in 1998, 65\% in 2000) compared with Protestants (57\% and $45 \%$ respectively) and the higher level of rejection of human evolution as definitely or probably untrue among Protestants $(37 \%$ and $38 \%$ ) than Catholics (18\% and 24\%). Recent research in 2009 published by Theos indicated that in a survey of over 2000 UK adults, NI was the region with the highest percentage of both young-earth creationists (25\%) and ID advocates (16\%; Lawes 2009). The NI portion of the sample was small $(N=60)$, and thus, it is difficult to make generalizations about NI attitudes to evolution based on this sample.

Two studies of secondary school students had been conducted by Francis and Greer $(1999,2001)$ in NI. Pupils $(n=2,129)$ aging between 13 and 17 years of age (in the third, four, fifth, and lower sixth years of secondary school), from a random sample (12 Catholic, 12 Protestant) of grammar $^{3}$ schools completed a questionnaire on their attitudes to creationism and evolutionary theory (Francis and Greer 1999). Almost half (48\%) of respondents agreed with the statement that "God created the world as described in the Bible," and of that, over one quarter (27\%) adopted a literal six days of twenty-four hours interpretation of creation. Francis and Greer reported that support for creationism (various conceptions) was higher among Protestants than Catholics, among girls than boys, and among younger (third and fourth year) students than older students (fifth year and lower sixth). Catholics were more likely than Protestants to articulate a view that science disproves the biblical account of creation, as were older students (fifth year and lower sixth) compared to younger students. A later study of 1,584 pupils aged 14-16 years found that "being female, being young, personal devotion, public church attendance and enrolment at a Protestant school were all associated with higher levels of belief in creationism" (Francis and Greer 2001: 48). The data also indicated that those holding creationist beliefs had a more positive view of Christianity and more negative view of science, while in contrast, those holding views consistent with "scientism," the view that "scientific theories attain to absolute truth" (ibid: 40), had a more favorable attitude to science and a less positive attitude toward Christianity. When controlled for scientism and creationism, attitudes toward Christianity and science were positively correlated.

\footnotetext{
${ }_{3}^{3}$ Students attending grammar schools in Northern Ireland typically have passed a selection test, known as the " $11+$ Transfer Test", in the final year of primary school. 2008 was the final year of this form of academic selection in NI.
} 
Francis and Greer suggest this is of importance to both religion and science educators, in that more sophisticated conceptions of both science (as fluid and provisional) and religion (as non-literal) may help pupils overcome negatively associating the two. Williams (2008a) notes that these studies have been conducted from the perspective of attitudes toward religion, rather than attitudes to sciencehighlighting the need for more attention to the issue from those engaged in research in science education.

\section{Attitudes of Science Teachers in the UK}

Research into attitudes toward evolution, particularly among UK science teachers is sparse (Williams 2008a). The observation that the activity of anti-evolutionists is worthy of consideration by science educators and educational researchers has prompted recent publication in the area (Jones and Reiss 2007) and the first published research in the UK into teacher attitudes regarding evolution and creationism (Cleaves and Toplis 2007). Cleaves and Toplis, in their interviews of 35 trainee and 29 experienced science teachers, report that although approximately two thirds $(69 \%)$ of their respondents would use the evidence available to support evolution, one third were willing to either accommodate "alternatives to the theory of evolution" or to present evolution as "just a theory." Cleaves and Toplis express "serious concern about whether all science teachers and prospective science teachers have a scientific view of evolution or have sufficient training to respond to 'alternative theories' in science lessons' (p.30). While the majority of those interviewed by Cleaves and Toplis viewed evolution as a valuable theory, one in eight of their participants felt it should be treated as a controversy.

A study by Teachers TV last November suggests 33\% of teachers agreed that creationism or ID should be "given the same status as evolution in the classroom" (2008). Of this sample of 1,200 primary and secondary education professionals, only 248 were science teachers, and it was selfselecting so not representative, but $18 \%$ of the science teachers responding supported creationism/ID having the same status as evolution in the classroom. Although the survey did not specify which classroom, given that evolution is taught as part of the National Curriculum for Science at Key Stages 4 and 5, it is reasonable to infer that the minority of science teachers who agreed with giving creationism/ID the "same status as evolution" would deem it appropriate to teach such concepts in the secondary school science classroom.

An Ipsos MORI poll in December 2008 indicated that less than half of all teachers and two thirds of science teachers surveyed object to creationism being taught in science, and a majority (65\%) favor "discussing" it. The poll of 923 primary and secondary teachers (across subjects) in England and Wales reveals that almost half (47\%) would not teach creationism alongside evolution and the big-bang, and in the science teachers surveyed, this figure rose to $65 \%$. These views are consistent with the government teaching directives (Department for Children, Schools, and Families 2007) on dealing with creationism in the science classroom. Of all teachers surveyed, 65\% think creationism should be "discussed," and interestingly, this figure rises among the science teachers (73\%).

A further question in the poll asked the extent to which respondents agreed with the statement: "the only reason to mention creationism in schools is to enable teachers to demonstrate why the idea is scientific nonsense." Only a quarter $(26 \%)$ of all teachers agree with this blunt rejection of creationism, and the figure rises to almost half in science specialists $(46 \%)$.

There are some problems with the survey. Many of the primary teachers involved, even those with a science specialty, are unlikely to be teaching evolutionary biology much - although primary school "The World Around Us" units do contain some aspects of classification and variation at Key Stage 2, the final stage of primary education in the UK. The questions also did not specify what sort of creationism is being discussed: young-earth, old-earth, progressive creationism, or intelligent design, to give some examples.

As is the case with the various public opinion polls, the Ipsos MORI and Teachers TV surveys, while problematic in phrasing of questions, do at least indicate that a minority of science teachers in the UK either claim to disagree with evolution outright or contend that non-scientific alternatives to evolution are deserving of being taught alongside evolution in the science classroom.

Given the evidence that some science teachers indicate a willingness to teach creationism, the growing visibility of various forms of creationism in NI, and the media attention it has attracted, this paper looks at how this visibility may affect biology teacher education, and with the paucity of research on attitudes to evolution in NI, especially among teachers, this study addresses two questions:

- What are the attitudes of pre-service science teachers in NI with regard to evolution, creationism, and intelligent design?

- Can pre-service biology teachers deal with potential challenges to evolution in the science classroom?

\section{Methods}

Sample This study comprised two components: The first aspect of the study involved a questionnaire of pre-service 
science teachers on attitudes toward evolution and creationism/ID ( $n=112$; mean age: 25.7 years; $25 \%$ male, $75 \%$ female) across the individual subjects (biology (33\%), chemistry $(25 \%)$, physics $(17 \%)$, and primary science $(25 \%))$. The majority of respondents were studying for the Postgraduate Certificate in Education (PGCE; $n=84)^{4}$, while the remainder $(n=28)$ were undertaking an undergraduate Bachelor of Education $(\mathrm{BEd})^{5}$ course of study. The second aspect of the study involved students $(n=49)$ enrolled on the PGCE biology course in two consecutive years of intake, 2006-2007 and 2007-2008, and comprised an activity in which students evaluated an intelligent design DVD and took part in focus groups about issues raised. A condition of entry to the PGCE biology course is that students have an undergraduate degree in a biological or biology-related science. Additionally, some participants had higher qualifications at the masters or doctoral level.

Questionnaire The questionnaire administered to 112 students in 2008 comprised a number of demographic items (gender, age, religion, course of study), three open-ended items on the nature of science (NoS) and evolution, and an evolution attitude scale, which incorporated items from existing scales (Rutledge and Warden 1999; Ingram and Nelson 2006). This paper intends to provide a snapshot of the attitudes of prospective science teachers in NI toward evolution and creationism and survey responses to challenges presented concerning evolution. Data relating to religious variables were collected in the questionnaire of 112 prospective science teachers, but not at the time of focus groups. Further research is under way, examining the effects of variables such as religious affiliation, selfidentified worldview, and religious upbringing, and it is the intention of the authors to build on the attitude snapshot presented in this paper.

Intelligent Design DVD Session and Focus Groups For the purposes of this research, 49 prospective biology teachers viewed the DVD Unlocking the Mystery of Life (Allen 2002). The DVD promotes the supposed "scientific alternative" to evolution, intelligent design. Participants were informed that the DVD had been sent to the science department of every UK secondary school and sixth-form college in September 2006 (Truth in Science 2006) and that

\footnotetext{
${ }^{4}$ The 1-year Postgraduate Certificate in Education is the traditional route into secondary-level science teaching in NI, although other initiatives such as Teach First and the Graduate Training Programme (GTP) are also available in other parts of the UK. Entrants to PGCE programs typically have a first degree in subject related to that they intend to teach.

${ }^{5}$ The Bachelor of Education degrees available in NI comprise a 4-year course of study combining professional studies, teaching experience and a subject specialism, in this case science. Traditionally, it is associated with primary, rather than secondary education.
}

the researchers were interested in their comments after viewing, but were not informed who had produced the DVD or distributed it to UK schools.

The DVD itself is well produced and resembles many resources commonly used in schools, with sophisticated animations, a wide array of wildlife footage, and the academic credentials of its contributors emphasized. Its content focuses both on presenting apparent problems or gaps in evolutionary theory and on advancing specific claims of ID theory. The standard examples presented in the DVD as evidence for ID have been criticized or disproven elsewhere (Pennock 1999; Shanks 2004; Young and Edis 2004; Brockman 2006; Scott and Branch 2006; Shermer 2006; Sober 2007; Miller 2008), and no positive evidence for the claims can be found in the academic literature. The DVD has also been criticized for misleading presentations of Darwin's trip on the HMS Beagle and emphasizing the "debate" over evolution while simultaneously failing to present the other side of the supposed debate, namely criticisms of ID (NCSE 2009, http://ncseweb.org/creationism/ analysis, accessed 2 April 2009). While ID itself is in one sense a restatement of older teleological arguments such as William Paley's "watchmaker," its modern usage has been shown to have its origins much more recently, as a tactical response to a 1987 court decision. In the case Edwards v. Aguillard, it was ruled that a Louisiana law requiring that creation science be taught alongside evolution in public schools was unconstitutional because it was intended to advance a particular religion. It has been demonstrated that the usage of the terms intelligent design and "intelligent design proponents" in place of creationism and "creationists," respectively, in various drafts of the creationist/ID textbook Of Pandas and People occurred as a direct result of this ban on teaching creation science, and this amounted to a strategic move in the ongoing attempts to undermine evolution education (Forrest 2005). This evidence contributed to Judge John E Jones III's opinion in the Dover Trial that intelligent design "cannot uncouple itself from its creationist, and thus religious, antecedents" (2005: 136). The DVD does not mention these stages in the evolution of ID, and only in the final few scenes are any metaphysical issues alluded to.

Participants were asked to complete a question sheet with five open-ended questions on various aspects of the resource:

1. What do you think of this DVD as an educational resource?

2. What did you learn about evolution from this resource?

3. What is intelligent design?

4. What else did you learn?

5. Did it make you think differently about any aspects of evolution? How/why? 
Table 1 Format of 2008 focus groups
Starter questions

To move into main questions

Main Questions

Key areas

Ending questions
What are your initial impressions or thoughts on the resource?

Were you familiar with any of these concepts before?

Did you learn anything from the educational resources viewed?

What do you think about the evolution/creationism/intelligent design controversy?

What do you think should be discussed in the science classroom regarding these topics and in what way? Would you discuss them elsewhere?

What would you say science is?

How do you decide what is/isn't a scientific theory?

If there was anything that could make a resource like that better, what might that be?

Has it made you think differently about any of the issues?
Following viewing the DVD and responding to the question sheets, the 2007 and 2008 sessions differed slightly. In the 2007 session $(n=28)$, a whole-class discussion was undertaken exploring the issues raised and debriefing the participants on the origin of the DVD and the fact many of the ideas contained within were not considered legitimate science by the majority scientific community (National Academies of Science 1999; The Royal Society 2006; Association for Science Education 2008) and that the UK government had indicated that the resource was not suitable to support the science curriculum (Randerson 2006). The participants were then given the opportunity to respond to a follow-up questionnaire asking how they felt about the resource and if they thought differently about using the resource once they knew more about it. The follow-up contained three open questions asking how participants felt about the resource after the whole-class discussion, whether it made participants think differently about how to use resources in the classroom and if they had any other comments concerning the relevant issues.

In the 2008 session $(n=21)$, DVD viewing was followed by dividing the class into four focus groups to discuss issues raised in the resource and to get a picture of the range of views within the class of new biology teachers and the reasons for holding them. The discussion groups were between 15 and 20 minutes long and involved following a script of questions in a semi-structured format. All focus groups were facilitated by qualified science education professionals. The format of the semi-structured focusgroup discussion is detailed in Table 1.

\section{Results}

Results 1—Pre-service Science Teacher Attitudes

The pre-service science teachers were asked to respond to items relating to what should be taught in science and their attitudes to special creation, human evolution, and common ancestry. When asked "what should be taught in science?", over one fifth $(21 \%)$ of participants indicated a preference for evolution only, with $8 \%$ opting for either creationism or ID only, while over two thirds of respondents (68\%) said they thought a "range of theories" should be taught in science (Fig. 1). The Ipsos MORI poll (2006), which asked a similar question, asked about each option individually, and so it is difficult to make a direct comparison between these pre-service teacher attitudes and those of the general public. However, given that two thirds of the pre-service science teachers here thought a "range of theories" should be taught in science and that $44 \%$ and $41 \%$ of the general public is reported as thinking creationism and ID, respectively, should be taught in science, it would appear that the prospective teachers surveyed do not differ markedly from the general public with regard to what should be taught in school science classes. Caution should be taken with the comparison - the presentation of all four options (evolution, creationism, ID, and "range of theories") in our study in a single item may make "range of theories" seems a "middle-ground" option.

On the topic of special creation, when asked to what extent they agreed or disagreed with the statement "a supreme being (e.g. God) created human beings pretty

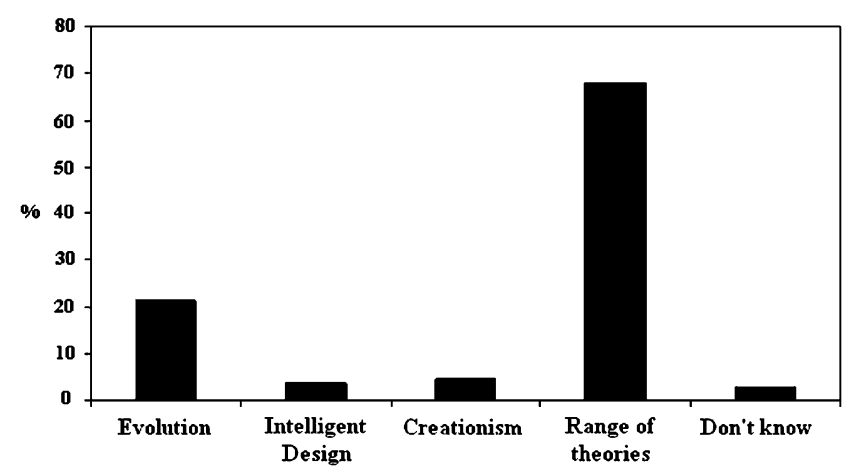

Fig. 1 What should be taught in science? 
Table 2 Sample attitude items (numbers refer to percentage responses to items)

\begin{tabular}{|c|c|c|c|c|c|c|}
\hline \multirow[t]{2}{*}{ Item } & \multicolumn{6}{|c|}{ Percentage } \\
\hline & $\begin{array}{l}\text { Strongly } \\
\text { agree }\end{array}$ & Agree & $\begin{array}{l}\text { Neither agree } \\
\text { nor disagree }\end{array}$ & Disagree & $\begin{array}{l}\text { Strongly } \\
\text { disagree }\end{array}$ & $\begin{array}{l}\text { Do not } \\
\text { know }\end{array}$ \\
\hline $\begin{array}{l}\text { A supreme being (e.g., God) created human beings } \\
\text { pretty much in their present form; humans did not } \\
\text { evolve from other forms of life (e.g., a fish and/or reptiles) }{ }^{\mathrm{a}}\end{array}$ & 17 & 13 & 21 & 17 & 30 & 4 \\
\hline There is evidence that humans evolved from other animals ${ }^{\mathrm{b}}$ & 21 & 41 & 13 & 12 & 9 & 3 \\
\hline $\begin{array}{l}\text { Over billions of years all plants and animals on earth } \\
\text { (including humans) descended (evolved) from a common } \\
\text { ancestor (e.g., a one-celled organism) })^{\mathrm{a}}\end{array}$ & 15 & 24 & 26 & 12 & 14 & 9 \\
\hline
\end{tabular}

a "Strongly disagree" answer most consistent with evolution

b "Strongly agree" answer most consistent with evolution

much in their present form; humans did not evolve from other forms of life (e.g. a fish and/or reptiles)," over one quarter $(29 \%)$ either agreed or strongly agreed, less than half $(47 \%)$ disagreed or strongly disagreed, and the remainder either did not know or were undecided (Table 2).

With regard to human evolution, approximately one fifth $(21 \%)$ of respondents disagreed or strongly disagreed with the statement "There is evidence that humans evolved from other animals," while almost two thirds (63\%) agreed/ strongly agreed with the statement, and the remainder were undecided or did not know (Table 2).

A central component of evolution is the common ancestry of all life. Respondents were presented with the statement "Over billions of years all plants and animals (including humans) descended (evolved) from a common ancestor (e.g. a one-celled organism)" (Table 2) —over one third (39\%) agreed or strongly agreed, approximately one quarter $(26 \%)$ disagreed or strongly disagreed, while the remainder were undecided (26\%) or did not know $(9 \%)$.

Results 2-Response to the Intelligent Design DVD

Overall impressions of the DVD were positive across the two biology PGCE year groups. Aspects commented on included the quality of animations/graphics, its stimulation of "debate" and being "informative," and more practical concerns about keeping students occupied and attentive (Fig. 2). Many commented on the length of the feature (60 minutes) being too long but still indicated an overall good impression - the resource itself comes in an alternate form of six 10-minute segments, which may render some of these comments less relevant for classroom use of the DVD. Negative and neutral impressions of the resource were indicated by a minority (14\% each) of respondentsnegative comments included those who though it was too content-heavy to be of utility at any level in secondary school, and two participants commented on a perceived bias, linking it to creationism/ID and showing an awareness of the background.

Of the comments relating to educational utility, most negative comments (23) concerned the level at which the resource is suitable, with many saying it is too advanced for school, in particular GCSE level. Positive comments regarding the educational utility related mainly to the diagrams (13) and animations (12; Fig. 2).

When asked what they had learned about evolution from the resource, the majority of participants (94\%) used language suggestive of an apparent perception of a scientific alternative to evolution, while the remainder $(6 \%)$ either rejected the claims as a form of creationism, religiously motivated, or a misunderstanding of the relationship between science and religion. When asked what they thought intelligent design was, only $6 \%$ indicated any skepticism over the scientific claims about ID advanced in the DVD, and the majority (94\%) appeared to take the DVD claims about intelligent design at face value. A subset (15\%) of this majority expressed opinions indicating an outright rejection of evolution or an acceptance of creationism or ID based on prior beliefs (Fig. 3).

Interestingly, some participants indicated that they thought that intelligent design is a current scientific theory under research, as evidenced by sample statements ${ }^{6}$ concerning the perceived scientific claims:

- Natural selection (Darwin's theory) is being rejected by many scientists in relation to how life began. [08p12]

- Most theories on evolution now focus on the basis of intelligent design and not natural selection. [07p03]

- Now believe that the origin of life is due to intelligent design. [07p05]

- Genetic information, transcription and translation. Whatever process designed, this code was very intelligent! [08p13]

\footnotetext{
${ }^{6}$ Participants are coded or given pseudonyms in any quoted passages in the text.
} 
Fig. 2 Comments concerning intelligent design DVD resource-grouped as positive or negative and according to whether they relate to educational aspects or interest/ enjoyment

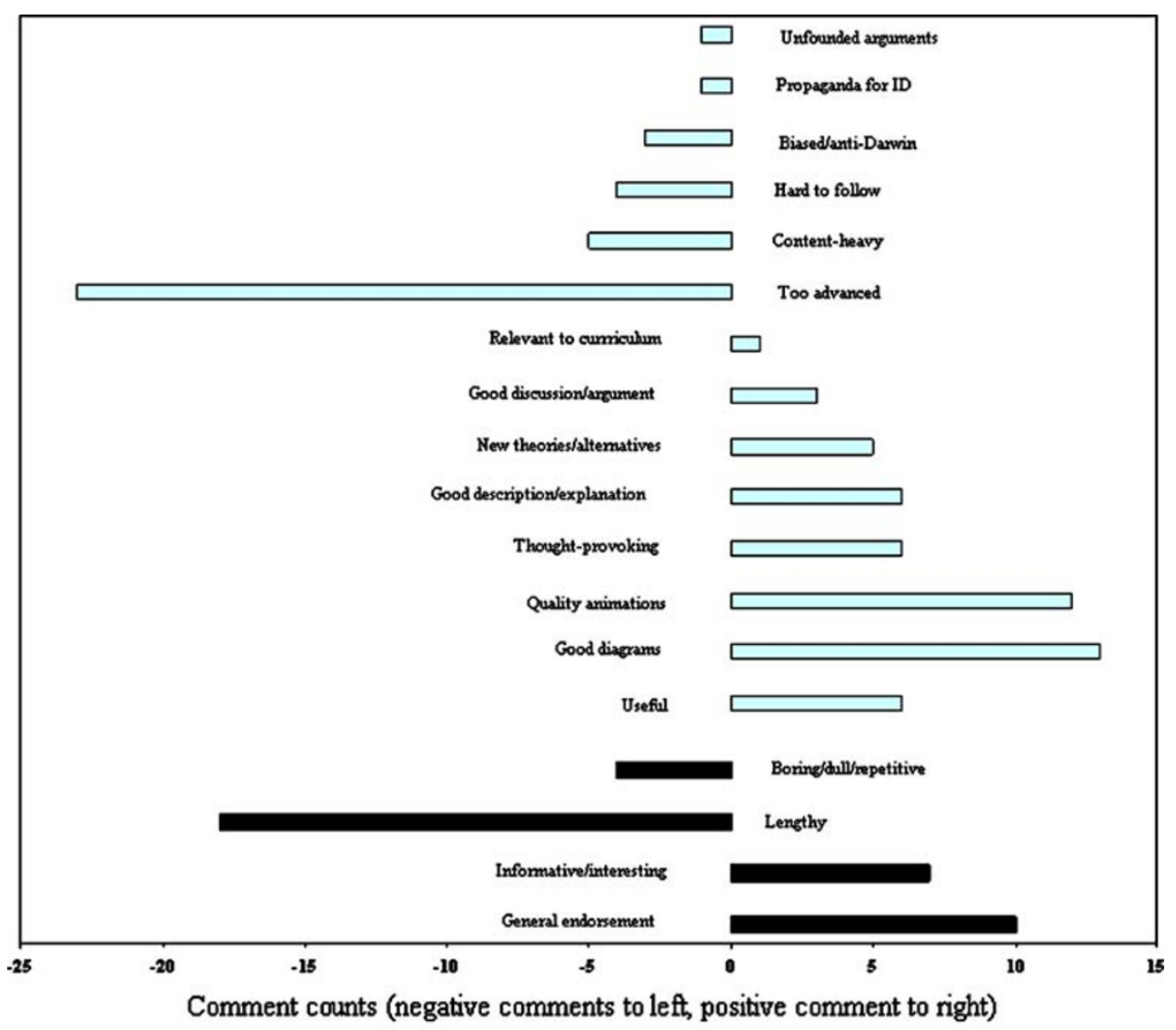

口Education \& learning Interest \& enjoyment
Nine out of ten participants perceived a legitimate scientific challenge to evolution. Less than one in ten challenged the claims in the DVD or was skeptical of its scientific credentials:

- Might be religious based, can't disprove it. [08p06]

- Scientists trying to scientifically justify their own faith in a "supreme being." [07p24]

- It is a slight alternative to creationism and was devised in America. Conveniently used to explain things without the need to examine or devise alternative and possibly more complex theories. [08p12]

When asked what level the resource was suitable for, two thirds felt it was only suitable for A level or higher, one participant said they would not use it at all, while the remainder $(32 \%)$ did not indicate a level preference-no participants said they thought it was suitable for GCSE level, despite the resource being targeted at that level.

\section{Results 3-Follow-Up Questionnaire and Focus Groups}

Following a debriefing discussion of the intelligent design DVD, seven participants in the 2007 PGCE biology group completed and returned a follow-up questionnaire. While the returned sample is small, it gives an indication of the shift in attitude toward the resource following debriefing. All seven said they would think very carefully about using classroom resources having found out the background to the Unlocking the Mystery of Life resource, but three said there were still some useful elements in the resource:

- I thought the resource was useful, political agenda or otherwise. This does not reduce the merit or value of

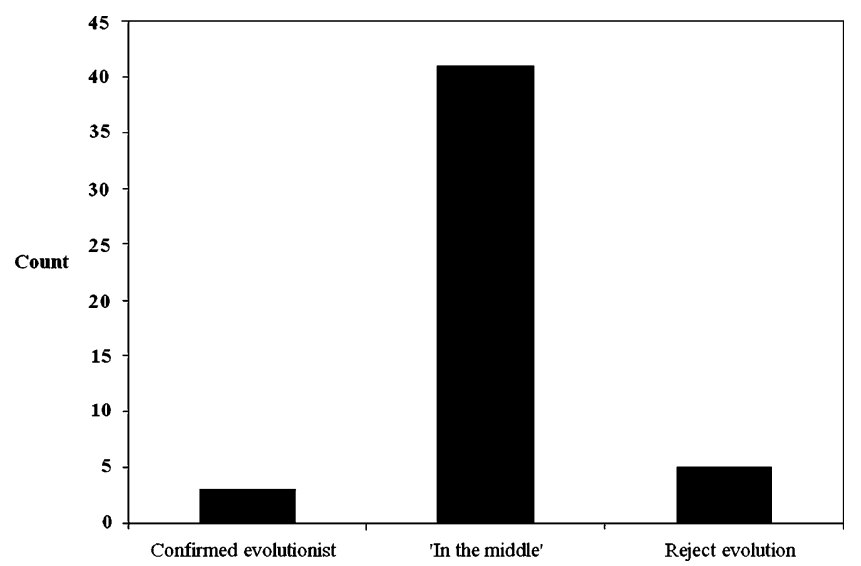

Fig. 3 Views expressed in response to DVD 
the DVD. It is useful for teaching different topics like transcription and translation and includes interesting information which would produce thought, debate, critical thinking etc. [FUp1]

Five of the seven returned said they were now aware of an agenda in the DVD:

- After discussion, I now feel that much more thought is needed before accepting what is said in the DVD. Also knowing the background/funding of the DVD has made me feel differently. [FUp4]

Two participants were clear that they felt the same after discussion and would not have shown it in the first place:

I didn't think I'd show it before and I probably wouldn't now some of the sections may be usable but most of it has no evidence to back it up. [FUp7]

In the 2008 session, focus-group discussions took place after viewing the DVD. Here, themes emerging from these focus-group discussions and DVD questionnaire responses are discussed, with a view to identifying the biology student-teacher ability to deal with the challenges to evolution posed in the ID resource.

Creationism vs. Evolution A minority of teachers revealed either confident evolutionist positions or strong creationist positions. Some participants indicated that they had a prior religious belief that they felt rules out evolution for them:

- I don't believe in evolution, I believe in creationism and I can't be swayed any other way and that's just me. [Kate, gp1]

- I've always believed in creationism because I'm a Christian and I've always believed that. [Jeff, gp1]

Others question the validity of evolution in science education:

- Well I had to teach evolution to year-12s when I was in school and some of them were asking do I believe in it, and I says 'no'. And they said 'well why are we learning it then?' And I said, 'well basically because it's on your syllabus and that's just tough.' [Anna, gp1]

A minority indicated confidence in their acceptance of evolution and prepared to challenge what they perceived as an attempt to advance creationism:

- What you have to think about that video is that I think they would listen to that and go "oh Darwinism is just rubbish and why even bother to teach me that?"... Like you say they just hear something and accept it as fact. Well I can't accept it as fact that this "proves" creationism, when it doesn't even prove that. [Suze, gp1]
"Theory Not fact" and "Teach the Controversy" The majority of participants in discussion did not indicate strong leanings to either creationism or evolution and were more accurately characterized by a "middle-ground" position. Typically, the language used in articulating their opinions indicated either a form of relativism, treating all theories as having scientific merit or as perceiving a legitimate scientific controversy with regard to creationism/ID's challenge to evolution.

- I think you have to make it clear as well that it's just theories. I mean nobody knows, and we're never gonna find out - no one's gonna come along and say "oh well this is how it happened" so y'know it's all theory. [Lisa, gp1]

- In the classroom, you're supposed to be promoting them to y'know, be scientists, and you can't really be proper scientists unless you have all of the theories, all the facts like. [Jason, gp3]

- ...leave it up to a debate, perhaps your pupils... like y'know and obviously freedom of speech everybody has their own ideas. But obviously let everyone... I suppose put forward all their ideas but obviously no one has the correct answer or a wrong answer. [Liz, gp2]

Some felt apprehensive about teaching evolution or a need to accommodate religion because of perceived controversy:

- I don't even feel, I suppose I'd be a bit of an atheist anyway, but I don't know that I would feel comfortable teaching something like evolution in the classroom because [...] you're not sure how to be middle of the road without putting your point of view across. And I wouldn't want to be... and some children are brought up by creationist parents and whatever and that's the way they want to be brought up so what do you do? [Lisa, gp1]

Intelligent Design as "New" or Current Science Most viewed ID as legitimate science, and few raised any skepticism:

- I think it's refreshing to see actual scientists, people who have believed in evolution and Darwinism and who have said "maybe we were wrong." [Jeff, gp1]

- Intelligent design is the beginning of a new theory on evolution. [07p2]

\section{Discussion and Implications}

Many points for discussion arise from this study-here, attitudes to evolution among new science teachers and confusion among new biology teachers over some core aspects of evolution and the nature of science will be 
discussed. In the "Conclusion" section, the potential effect of the growing visibility of creationism in NI is addressed, with these implications of the findings in mind.

Attitudes to Evolution-Conception and Relative Acceptance of Evolution

This study raises issues for the acceptance of some fundamental aspects of evolution among those surveyed. In the preliminary analysis of attitude items, many preservice science teachers indicated views at odds with scientific consensus:

- Almost 30\% agreed with a statement to the effect that humans did not evolve and were specially created in their present form by a "supreme being."

- Approximately one fifth doubted that there is evidence for human evolution.

- Over one quarter disagreed with the concept of all life sharing a common ancestor over time spanning several billion years.

While these are sample items from an ongoing study, they provide an interesting snapshot of the attitudes toward some fundamental evolutionary concepts. Some researchers have found that attitudes toward evolution are linked to epistemic views, particularly knowledge about the nature of science (Hofer et al. 2006; Lombrozo et al. 2008), which highlights the importance of a multi-faceted approach to the defense of evolution in science education. Understanding evolution does not necessarily lead to acceptance (Sinatra et al. 2003; Lombrozo et al. 2006; McCall and Cavallo 2006), and in this sample, possessing an undergraduate biology education does not necessitate the acceptance of some fundamentals of evolution. This begs the question of whether it is sufficient for teachers to understand but not necessarily accept the science they are teaching. Given the centrality of evolution as a unifying principle in biology, this question deserves attention in the future. If understanding does not necessarily lead to acceptance, it is not good enough to simply teach more of the science-but rather "how science works as a method" (Pigliucci 2007: 285). Williams $(2008 b, c)$ reports that many prospective science teachers had misconceptions about key terms relating to the nature of science - "fact," "law," "theory," "hypothesis." If one cannot understand the definition of key terms that distinguish between science and other ways of knowing, how can one differentiate between science and non-science in the classroom? That many of those surveyed were also at least temporarily persuaded by the Unlocking the Mystery of Life DVD resource while also holding "fuzzy" notions about the nature of science, and some even rejecting evolution, has important implications for science education at all levels, given that the participants were educated in science to degree level. It may also be useful to present prospective teachers with the variety of religious attitudes to evolution (Scott 2000) and to make them aware of the government directives on evolution education (Department for Children, Schools and Families 2007) and of what is or is not a legitimate scientific debate over evolution (e.g., gradualism vs. punctuated equilibrium, socio-biology, etc.).

Confusion_-"Just a Theory" and "Teach the Controversy"

That many articulated views consistent with the appeals to fairness and "balance," as typified by their adopting a "teach the controversy," "just a theory," or "teach both sides" point of view, raises concerns over the ability of new teachers to distinguish between scientific and non-scientific theories, as such positions are characteristic of many attempts to undermine evolution education (Scott and Branch 2003; Scott 2007). More fundamentally, these positions indicate common misconceptions (Branch and Mead 2008; Gregory 2008) among many respondents about the nature of scientific theories - the everyday notion of a theory as a "hunch," "idea," or "guess," differs considerably from the scientific conception, which is a substantiated explanation of some aspect of the natural world that incorporates observations, facts, laws, and is testable and open to scrutiny by peers. When these views are coupled with the finding that over two thirds of pre-service science teachers surveyed indicated a preference for teaching a "range of theories" in science, there is cause for concern.

The "controversy" about which anti-evolutionists speak often refers to whether evolution can explain the abundance and complexity of life we observe and posits that creationist or ID explanations are better at explaining the data. It is widely acknowledged that creationism/ID are not considered legitimate scientific theories and lack meaningful support within the scientific community (Young and Edis 2004; Numbers 2006; Lewens 2007; Sarkar 2007), and given the absence of positive evidence in support of creationism or intelligent design in the peer-reviewed scientific literature, the issue should not be presented as if there are opposing sides in a legitimate scientific controversy (Alters and Alters 2001; Scott 2007; Scott and Branch 2003). By treating the issue as if it were indeed a legitimate controversy is to give anti-evolutionists the "oxygen of respectability" (Dawkins 2003: 218). That is not to say that evolution should be presented as if it is without controversy-indeed an indicator of healthy science is the existence of ongoing debates. Some scientists and educators have been keen to present the types of scientific controversies that may be worth the attention in the science classroom with regards to evolution, such as phyletic gradualism vs. punctuated equilibrium, evolutionary explanations of human behavior, the targets and levels 
of selection, and natural selection vs. genetic drift (Dawkins and Coyne 2005; Alters 2006; Williams 2008a). The Association for Science Education is clear about the supposed scientific controversy relating to ID: "Intelligent Design, with no foundation in scientific methodology, cannot be classed as science, not even bad or controversial science" (Association for Science Education 2008).

That said, "teaching the controversy" has also been used in a sense that does not explicitly endorse non-scientific alternatives. Recent cases in the USA have shown attempts to undermine evolution education by presenting evolution as a theory in crisis by emphasizing "strengths and weaknesses" language in school science standards (Bhattacharjee 2009) or highlighting evolution as a controversial issue that "promotes critical thinking skills" alongside global warming and human cloning (Richards 2008: 1572). Regardless of the manifestation, the intent is to undermine evolution education and advance a particular religious agenda. With such motives in mind, it is interesting to note that the prospective biology teachers shared an apparent consensus view that the DVD was unsuitable to support the GCSE curriculum, and many felt it was even beyond A level students. The authors also had this impression upon first viewing the resource, which brings into question the motivations of TiS in targeting the resource at GCSE level. Could it be that with the content-heavy and technical language, coupled with the oft-commentedupon animations, that there is intent to "blind with science" and betray an air of legitimacy to the resource content?

\section{Conclusion}

A prompt for this study was the unsolicited distribution of an ID resource DVD to UK secondary school science departments and a growth in the visibility of creationism in NI specifically. Most of the prospective teachers who viewed the DVD in this study accepted the ID arguments in the resource at face value, many accepting ID as current science, while only a small minority criticized ID. Although a minority of pre-service teachers expressed views consistent with the polar ends of what is termed the evolution/ creation continuum (Scott 2000), most of those who viewed the DVD were deemed "in the middle" and somewhat malleable with regards their position on these issues. At the polar ends, the DVD appeared to have little effect-firm evolutionists and firm creationists appeared to have already made up their minds - the "middle" position appears to be where the DVD claims had the greatest influence. That those in the follow-up questionnaire sample said they would reconsider using the DVD upon a de briefing about its origin and background suggests that it may be possible to minimize the persuasion of such resources by informing new teachers of the non-scientific nature of creationism/ID. Unless the issue is addressed directly, there is a danger that such a resource might influence how new teachers approach the topic of evolution in schools.

Williams (2008a) noted the paucity of research on issues relating to creationism/ID in science education in the UK and particularly of teacher attitudes toward evolution. The research that does exist raises some doubts about whether science teachers have a scientific conception of evolution and have the ability to deal appropriately with challenges to evolution in the science classroom (Cleaves and Toplis 2007). More recent work, as yet unpublished, is being reported as suggesting that only $12 \%$ of science teachers said the discussion of creationism was "very controversial" and that $33 \%$ of science teachers believe that a divine being played a role in the development of humans (Bloom 2008; Paton 2008). Calls have also been made for more up-to-date evidence for evolution to be used in the science classroom (Moore 2008; Williams 2008a). The slow uptake of modern evidence for evolution in the classroom, the attempts by anti-evolutionists to undermine Darwin's legacy and evolution generally, and the questionable confidence of some teachers in dealing with challenges in the classroom do raise concerns.

This paper described some of the attitudes held by preservice teachers in NI toward evolution and creationism and how they impact on their ability to deal with challenges to evolution and has added to this under-researched area. Some new science teachers do not accept evolution, despite the overwhelming support for it from the scientific community, and the majority of biology teachers in the present study were persuaded by the arguments put forward in an intelligent-design resource pack. Defending evolution against such superficial challenges from non-scientific alternatives requires science teachers to have a better conception of the nature of science, which could be informed by an understanding of the history of science and its philosophical foundations (Williams 2008b). It could be useful to make pre-service teachers aware of the variety of religious positions on evolution, the legitimate scientific controversies over evolutionary mechanisms or applications, and of the UK teaching directives regarding creationism.

This work is part of ongoing research that will also further investigate the factors affecting teacher attitudes toward evolution and creationism and in what way. A better picture of the views of teachers toward the relevant issues could inform both science curriculum and teacher education, with a view to assisting the next generation of teachers in representing their subject accurately, particularly with regard to the nature of science, the evidential nature of evolution, and the majority support it has within the 
community of scientists. Only by identifying attitudes toward the relevant issues, including any misconceptions concerning the nature of science and evolution generally, can it be hoped that the attempts to undermine evolution education can be defended against by those in a key position to do so-classroom science teachers. The implications of these findings raise a number of important questions and general points:

- The DVD resource persuaded many new teachershow should science educators respond?

- These new teachers took an unsolicited resource at face value - the same DVD had been sent to all UK secondary schools. How can new teachers be helped to make critical judgments about what resources are suitable to support the curriculum?

- The issue of creationism receives much press coverage and, as such, is something that teachers may be confronted with in the science classroom-how can new teachers be assisted to deal with the challenges appropriately?

- Given that the government, science educators, and major scientific academies have come out strongly in favor of evolution and against variants of creationism, this study indicates that many prospective science teachers are still unaware of this-how can this disconnect be overcome?

\section{References}

Allen L. Unlocking the mystery of life: the scientific case for intelligent design. DVD. California: Illustra Media; 2002.

Alters B. Evolution in the classroom. In: Scott EC, Branch G, editors. Not in our classrooms: why intelligent design is wrong for our schools. Boston: Beacon; 2006. p. 105-29.

Alters BJ, Alters S. Defending evolution in the classroom: a guide to the creation/evolution controversy. Sudbury: Jones and Bartlett; 2001.

ARK. Northern Ireland Life and Times Survey 1998. 1999. http:// www.ark.ac.uk/nilt/1998/. Accessed 15 June 2008.

ARK. Northern Ireland Life and Times Survey 2000. 2001. http:// www.ark.ac.uk/nilt/2000/. Accessed 30 Mar 2009.

Association for Science Education. Science education, intelligent design and creationism: A statement from the association for science education. Sch Sci Rev. 2008;90(330):12-3.

BBC News. Paisley to quit as first Minister. 2008. http://news.bbc.co. uk/1/hi/northern_ireland/7277886.stm. Accessed 22 Aug 2008.

BBC Northern Ireland. The politics show. Television broadcast 21 October 2007. Belfast: British Broadcasting Corporation; 2007.

BBC Radio Ulster. Good morning Ulster. Radio broadcast 23 October 2007. Belfast: British Broadcasting Corporation; 2007.

BBC Radio Ulster. Sunday sequence: rescuing genesis. Radio broadcast 31 August 2008. Belfast: British Broadcasting Corporation; 2008.

Belfast Telegraph. Viewpoint: the world, according to Lisburn folk. 2007. http://www.belfasttelegraph.co.uk/opinion/viewpoint-theworld-according-to-lisburn-folk-13479536.html. Accessed 25 Oct 2008 .
Bhattacharjee Y. New Texas standards question evolution, fossil record. Science. 2009;324(5923):25.

Bloom A. God and science. 2008. http://www.tes.co.uk/article.aspx? storycode $=6002623$. Accessed 10 Oct 2008 .

Branch G, Mead L. "Theory" in theory and practice. Evo Edu Outreach. 2008;1(3):287-9.

British Centre for Science Education. Truth in science. 2007a. http:// bcseweb.org.uk/index.php/Main/TruthInScience. Accessed 30 March 2009.

British Centre for Science Education. Take heed ministries. 2007b. http://bcseweb.org.uk/index.php/Main/TakeHeedMinistries. Accessed 30 Mar 2009.

Brockman J, editor. Intelligent thought: science versus the intelligent design movement. New York: Vintage; 2006.

Brumfiel G. Intelligent design: who has designs on your students' minds? Nature. 2005;434(28):1062-65.

Cleaves A, Toplis R. In the shadow of intelligent design: the teaching of evolution. J Bio Edu. 2007;42(1):30-5.

Coalition of Scientific Societies. Evolution and its discontents: a role for scientists in science education. FASEB J. 2008;22(1):1-4.

Dawkins R. A devil's chaplain: selected essays. London: Weidenfeld \& Nicolson; 2003.

Dawkins R, Coyne JA. One side can be wrong. 2005. The Guardian. 1 Sept 2005.

Dawson G. Statements: intelligent design. 2006. http://www.george dawson.org/design.htm. Accessed 1 Mar 2007.

Discovery Institute. About discovery: mission statement. 2007. http:// www.discovery.org/about.php. Accessed 29 May 2007.

Dumigan N. Darwin latest target of DUP as creationists challenge evolution. 2008. Available at: http://www.irishtimes.com/news paper/ireland/2008/0807/1218047756470.html (accessed 8 August 2008).

Forrest B. Supplement to Expert Witness Report. Kitzmiller et al. v. Dover Area School District. 2005. Available at: http://www. creationismstrojanhorse.com/Forrest_supplemental_report.pdf. Accessed 8 Jun 2009.

Francis LJ, Greer JE. Attitudes towards creationism and evolutionary theory: the debate among secondary pupils attending catholic and Protestant schools in Northern Ireland. Public Underst Sci. 1999;8:93-103. doi:10.1088/0963-6625/8/2/302.

Francis LJ, Greer JE. Shaping adolescents' attitudes towards science and religion in Northern Ireland: the role of scientism, creationism and denominational schools. Res Sci Technol Educ. 2001;19 (1):39-53.

Gregory TR. Evolution as fact, theory, and path. Evo Edu Outreach. 2008;1(1):46-52.

Henry LA. Tussle of Biblical proportions over creationism in Ulster classrooms. 2007. http://www.belfasttelegraph.co.uk/news/education/ tussle-of-biblical-proportions-over-creationism-in-ulster-classrooms13479246.html. Accessed 30 Sept 2008.

Hofer BK, Lam CF, Hopkinson A. Understanding evolutionary theory: issues of epistemology, science education, and conceptual change. 2006. Text of paper presented at the annual meeting of the American Educational Research Association. April

Holden C. Ohio school board boots out ID. Science. 2006;311 (24): 1083 .

Ingram EL, Nelson CE. Relationship between achievement and students' acceptance of evolution or creation in an upper-level evolution course. J Res Sci Teach. 2006;43(1):7-24.

Ipsos MORI. BBC survey on the origins of life. 2006. http://www. ipsos-mori.com/content/bbc-survey-on-the-origins-of-life.ashx. Accessed 1 Sept 2008.

Ipsos MORI. Teachers dismiss calls for creationism to be taught in school science lessons. 2008. http://www.ipsos-mori.com/content/ home-page-news/teachers-dismiss-calls-for-creationism-to-betaugh.ashx. Accessed 1 Ap 2009. 
Jones JE. Memorandum opinion: Kitzmiller, et al. v. Dover School District, et al. 2005. Available at: http://www.pamd.uscourts.gov/ kitzmiller/kitzmiller_342.pdf. Accessed 1 Ap 2009.

Jones LS, Reiss MJ, editors. Teaching about scientific origins: taking account of creationism. New York: Peter Lang; 2007.

Lawes C. (2009) Faith and Darwin: harmony, conflict, or confusion? http://campaigndirector.moodia.com/Client/Theos/Files/Theos FaithandDarwin.pdf. Accessed 29 Mar 2009.

Lewens T. Darwin. London: Routledge; 2007.

Lombrozo T, Shtulman A, Weisberg M. Letters: the intelligent design controversy: lessons from psychology and education. Trends Cogn Sci. 2006;10(2):56-7.

Lombrozo T, Thanukos A, Weisberg M. The importance of understanding the nature of science for accepting evolution. Evo Edu Outreach. 2008;1(3):290-8.

McCall D, Cavallo A. Nature of science, beliefs in evolution, and scientific understandings: the great disconnect. 2006. Text of presentation at Annual Conference of the American Education Research Association. 7 April.

Miller KR. Only a theory: evolution and the battle for America's soul. New York: Viking Penguin; 2008.

Miller JD, Scott EC, Okamoto S. Public acceptance of evolution. Science. 2006;313(11):765-6.

Montgomery I. (2007) Creationism undermines our 'knowledge-based economy'. http://prod.belfasttelegraph.co.uk/opinion/letters/ creationism-undermines-our-knowledgebased-economy-13500028. html. Accessed 5 Nov 2008.

Moore A. Science teaching must evolve. Nature. 2008;453(1):31-2.

National Academy of Sciences. Science and creationism: a view from the national academy of sciences. 2nd ed. Washington: National Academy Press; 1999.

National Center for Science Education. (2009) Creationism: analysis. http://ncseweb.org/creationism/analysis. Accessed 2 Apr 2009.

News Letter. Call to teach biblical creation as science. 2008. http:// www.newsletter.co.uk/news/your-views-Call-to-teach.4360514. jp. Accessed 10 Nov 2008.

Northern Ireland Assembly. Friday 21 September 2007: written answers to questions. 2007a. http://www.niassembly.gov.uk/qanda/ 2007mandate/writtenans/070921.htm\#4. Accessed 25 Sept 2007.

Northern Ireland Assembly. Friday 23 November 2007: written answers to questions. 2007b. http://www.niassembly.gov.uk/qanda/ 2007mandate/writtenans/071123.htm\#4. Accessed 3 Dec 2007.

Northern Ireland Assembly. Education committee. 2008a. http://www. niassembly.gov.uk/education/2007mandate/educationhome_07. htm. Accessed 5 Sept 2007.

Northern Ireland Assembly. Friday 11 January 2008: written answers to questions. 2008b. http://www.niassembly.gov.uk/qanda/ 2007mandate/writtenans/080111.htm. Accessed 4 Feb 2008.

Numbers RL. The Creationists: from scientific creationism to intelligent design. Expandedth ed. Cambridge: Harvard University Press; 2006.

Paton G. Creationism should be taught in science lessons, say teachers. 2008. http://www.telegraph.co.uk/news/uknews/ 2988753/Creationism-should-be-taught-in-science-lessons-sayteachers.html. Accessed 10 Oct 2008.
Pennock RT. Tower of Babel: the evidence against the new creationism. Cambridge: MIT Press; 1999.

Pigliucci M. The evolution-creation wars: why teaching more science just is not enough. McGill J Educ. 2007;42(2):285-306.

Randerson J. Revealed: rise of creationism in UK schools. 2006. The Guardian, 27 November 2006, p.1.

Richards F. Louisiana opens school door for opponents of evolution. Science. 2008;320(5883):1572.

Rutledge ML, Warden MA. The development and validation of the measure of acceptance of the theory of evolution instrument. Sch Sci Math. 1999;99:13-8.

Sarkar S. Doubting Darwin? Creationist designs on evolution. Oxford: Blackwell; 2007.

Scott EC. The Creation/Evolution Continuum. 2000. http://ncseweb. $\mathrm{org} / \mathrm{creationism} / \mathrm{general} / \mathrm{creationevolution-continuum.} \mathrm{Accessed}$ 1 Nov 2008.

Scott EC. What's wrong with the "teach the controversy" slogan? McGill J Edu. 2007;42(2):307-3126.

Scott EC, Branch G. Evolution: what's wrong with "teaching the controversy". Trends Eco Evo. 2003;18(10):499-502.

Scott EC, Branch G. Not in our classrooms: why intelligent design is wrong for our schools. 1st ed. Boston: Beacon; 2006.

Shanks N. God, the devil, and Darwin: a critique of intelligent design theory. Oxford: Oxford University Press; 2004.

Shermer M. Why Darwin matters: the case against intelligent design. 1st ed. New York: Times Books; 2006.

Sinatra GM, Southerland SA, McConaughy F, Demastes JW. Intentions and beliefs in students' understanding and acceptance of biological evolution. J Res Sci Teach. 2003;40(5):510-28.

Sober E. What is wrong with intelligent design? Q Rev Biol. 2007;82 (1):3-8.

Spencer N, Alexander D. Rescuing Darwin: God and evolution in Britain today. 2009. http://campaigndirector.moodia.com/Client/ Theos/Files/RescuingDarwin.pdf. Accessed 22 Mar 2009

Teachers TV. Third of teachers would give creationism the same status as evolution in classrooms. 2008. http://www.teachers.tv/node/ 32677. Accessed 31 Mar 2009

The Royal Society. Royal Society statement on evolution, creationism and intelligent design. 2006. http://www.royalsoc.ac.uk/news. asp?id=4298. Accessed 1 Mar 2007.

Truth in Science. Resource pack. 2006. http://www.truthinscience.org. uk/site/content/view/43/92/. Accessed 29 October 2008.

Ulster Star. DUP call for schools to teach creation passed by council. 2007. http://www.lisburntoday.co.uk/news/creation-motionpassed-by-council.3233193.jp. Accessed 27 Oct 2008.

Williams J. Creationist teaching in school science: a UK perspective. Evo Edu Outreach. 2008a;1(1):87-95.

Williams J. What Makes Science 'Science'? 2008b. Scientist. 22:10. http://www.the-scientist.com/2008/10/1/29/1/. Accessed November 1, 2008.

Williams J. The scientific method and school science. J Coll Sci Teach. 2008c;38(1):14-6.

Young M, Edis T, editors. Why intelligent design fails: a scientific critique of the new creationism. Rutgers University Press: New Brunswick; 2004. 